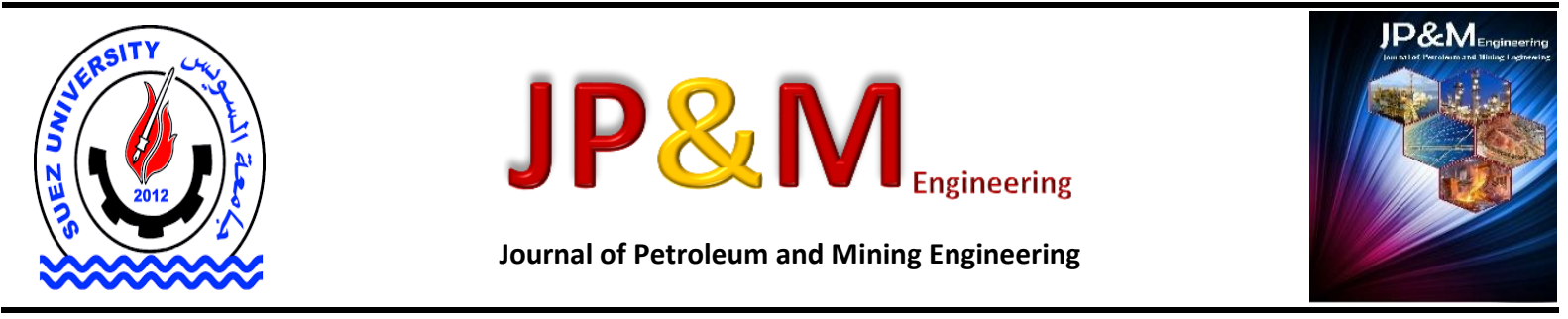

\title{
On the Modified Design of Anode Assembly in Hall-Héroult Cell Using Finite Element Method
}

\author{
Ali, M.M and Aly, M.A* \\ Mining and Petroleum Engineering Dept., Faculty of Engineering, Al-Azhar University, Qena- Egypt, \\ *Corresponding author: Mahmoud.a.aly@azhar.edu.eg
}

\section{Article Info}

Received 10 Jun. 2020 Revised 7 Jul. 2020 Accepted 16 Jul. 2020

\section{Keywords}

Finite element method; Anode assembly; Hall-Héroult cell; Design of steel stubs; Energy

\begin{abstract}
The Hall-Héroult process is the most commonly used process for aluminium production through an electrolytic reduction of alumina dissolved in an electrolytic bath at $960^{\circ} \mathrm{C}$. The voltage drop for the anode group represents about $8 \%$ of the total cell voltage. The resistance between the connections that link the different parts of the anode assembly causes the increase the anode voltage during the electrolysis process. The factors affecting the anodic voltage drop, temperature and stresses distribution were investigated using the finite element method (FEM). These factors included the stub diameter, thimble flutes number and steel stub number. Thermal and electrical measurements were carried out on ten prebaked anodes cells to verify and validate the modelled result. In this paper, study the electro thermal model under the influence of mechanical loading of the anode assembly confirmed that the design of the steel stubs (in terms of diameter and number) are the main factors that greatly influence the reduction of the anodic voltage, while the thimble flutes number might have a little effect on the anodic voltage drop.
\end{abstract}

\section{Introduction}

The Hall-Héroult process for the electrolytic reduction of alumina was patented at 1886 and is still currently the only industrial process for the production of aluminium. It is based upon the electro reduction of alumina in an electrolytic bath using anode blocks at about $960^{\circ} \mathrm{C}$ [1]. The actual energy consumption of this process is ranged between 13-14 $\mathrm{kWh} / \mathrm{kg}$ aluminium [2], while the theoretical value is about $6.34 \mathrm{kWh} / \mathrm{kg}$ aluminium at $977^{\circ} \mathrm{C}$ [1-3]. Lowering the anodic voltage drop $\left(A_{v d}\right)$ by $1 \mathrm{mV}$ can be saved $3.2 \mathrm{kWh} / \mathrm{kg}$ aluminium [4]. Hence, a massive efforts has been invested to reduce the electrical energy consumption to be $11 \mathrm{kWh} / \mathrm{kg}$ aluminium by 2020 [5]. Therefore, smelter operators see this as an effective way to reduce energy consumption in the Hall-Héroult cell. Previous studies concluded that the best approach to improve the energy efficiency can be achieved by the anodic voltage saving [4-8].

Most aluminium smelters currently operate at a total cell voltage of about 4.2 volts [9]. The voltage loss on the anode assembly represents about $8 \%$ of the total cell voltage [10]. Most of consumed energy is found in the contact area between the cast iron and carbon block [3].

The steel stubs are placed in holes in the anode block, and between them a cast iron is casted. The cast iron significantly shrinks after freezing, and an air gap leads to a significant decrease in the electrical conductivity of the anode block when installed in the cell [11]. The size of the air gap is determined based on the voltage drop value when connecting the anode [7, 11, 12].

When the anode assembly is immersed into the molten electrolyte during cell operation at $960^{\circ} \mathrm{C}$, the heat penetrates through the anode block and transfers to the rest of the anode assembly by conduction phenomena. Subsequently, the steel stub expands over time because of the elevated temperature.

In addition the anode block has to be changed after regular times, and the stubs must be repaired before using in another anode cycle [13]. Deterioration of the stubs has a negative effect on the anode performance $[5,14]$. The resistance for electrical and thermal interface has a significant effect on the Avo [4].

Ali et al. [15] investigated various types of cast iron, and compared with the existing high phosphorous gray iron (HPGI). The voltage saving between gray iron with carbon equivalent $=4.5$ and the $\mathrm{HPGI}$ was $23 \mathrm{mV}$.

Molenaar et al. [16] have proved that anode design is the key option to increase amperage with reduce in voltage drop by using 3D FEM for anode assembly.

Jing Liu et al. [17] developed 3D different surfaces of anode structure using ANSYS, to study the influence of current, temperature, thermal stresses, and voltage drop distribution over anode assembly. 
Jeddi [8] developed TEM model of a whole hexapod anode assembly, and showed that as the stub diameter increases the $A_{v D}$ decreases.

Additionally, Brimmo et al. [18] have presented alleviating procedures for the anodic voltage drop $\left(A_{v D}\right)$ problem. These procedures included choosing suitable thermal and mechanical properties for steel stubs and adjusting the thimble geometry in order to increase the contact area. These procedures helped to reduce the resistance of the electrical contact, and thus reducing the voltage drop on the anode.

A FEM is considered as an effective analysis tool that has diversity and flexibility $[19,20]$.

The aim of this study is using the FEM to study and characterization the thermal-electrical-mechanical (TEM) behavior of the anode assembly based on actual measurements carried out on ten cells for validation of the model. The stub diameter, thimble flutes number, and steel stub number were investigated to obtain the best design.

\section{Model analysis and Experimental works}

\section{A. Thermo-electro-mechanical model}

FEM based on the ANSYS academic student v16.1 workbench [21] was employed for solving the partial differential numerical equations of the anode assembly at Egyptalum smelter. The used model for analysis includes all the necessary information for each step of numerical solution: geometry preparation, suitable element for the analysis and meshing, preparation of the material properties, boundary conditions, solution of system equations, model verification visualization, and output of results.

The major challenge in constructing a finite element is in a geometry creating, meshing and model boundary condition description. The used anode consists of aluminium stud, steel yoke and four steel stubs. The steel stubs are placed in the holes in anode block and joined using HPGI.

The basic steps for anode modeling are illustrated in Figure $1(a, b)$. The holes dimensions in the anode block, flutes dimension and number are mentioned elsewhere [22]. The transition joint between aluminium stud and stub is neglected in this study. Tetrahedral element was selected as a suitable element for the model analysis and meshing to underestimate the strain and stress level and to increase the rigidity of the mechanical properties [7]. The most important selection points is to apply a fine mesh at locations, where the temperature, voltage and stress distribution are expected to be high [23].

The used meshing methods were sizing and contact sizing method, the sizing method was implemented in two stages. The first one was applied to the body of cast iron with element size of 0.02 meters, and the second was applied to the rest parts of the model with element size of 0.05 meters. The contact sizing was applied at all contacts regions with element size of $0.01 \mathrm{~m}$.

Number of elements and nodes of the model were 122767 and 222239, respectively. The material properties of the anode assembly have been reported elsewhere $[5$, $8,10,24,25]$.

\section{B. Boundary conditions}

The detailed of thermal and electrical boundary conditions used in this study were discussed in elsewhere $[17,34]$. Temperature-dependent thermal, electrical and mechanical properties were applied. The heat will mainly flow out from the top surface of anode, yoke surfaces, steel stub and aluminium stud. The convective heat transfer coefficients are calculated for each part of anode assembly and mentioned elsewhere [24]. Anode surfaces were flat and the selected anode is assumed to be representative of cell behavior. Immersion height of the anode into the bath is $150 \mathrm{~mm}$ with bath temperature of $960{ }^{\circ} \mathrm{C}$. The connected bio-metal between steel stub and aluminium stud was neglected. The contact resistance of cast iron and carbon block, and stub and cast iron is assumed to be a constant. Zero voltage is prescribed the bottom of anode block. $8917 \mathrm{~A}$ is applied at the top surface of the aluminium stud [26, 34]. The impact of air gap on the contact resistances varied with temperature and pressure and taken into account as mentioned elsewhere $[23,24]$. The air gap decreases as the stub diameter increases at different positions of the contacted area, and hence increases the contact resistance of the anode connection [23, 24]. Effect of yoke bending and impact of stubs deterioration on their geometry is not quantified and don't tak en into account in this study.

To mimic the actual cell, the anode block was fixed at the top of the aluminium stud, where clamped to the anode beam of the cell as shown in Figure 2. The applied mechanical loads in the model are the force $(A)$ resulting from the weight of the anode carbon block and steel stub on the bath, and the applied force ( $\mathrm{C}$ ) is at the bottom of the anode block taken into account the buoyancy force exerted by the bath. These forces similar to previous publications [5, 8, 27-29]. Weight of anode assembly was considered. It is hypothesized that no internal force is generated.

A coupling of TEM model under a steady-state condition of the cell was achieved taking into account the mechanical contact due to thermal expansion, ohmic heating, displacement and electrical contact resistance. The thermal- electrical problem was first solved and used to update the model's thermal solution. The obtained result fed to the mechanical problem. This result influences again the initial temperature distribution which leads to new processing of the thermal- electrical problem. Once the TEM solutions are done, the problem is converged. 


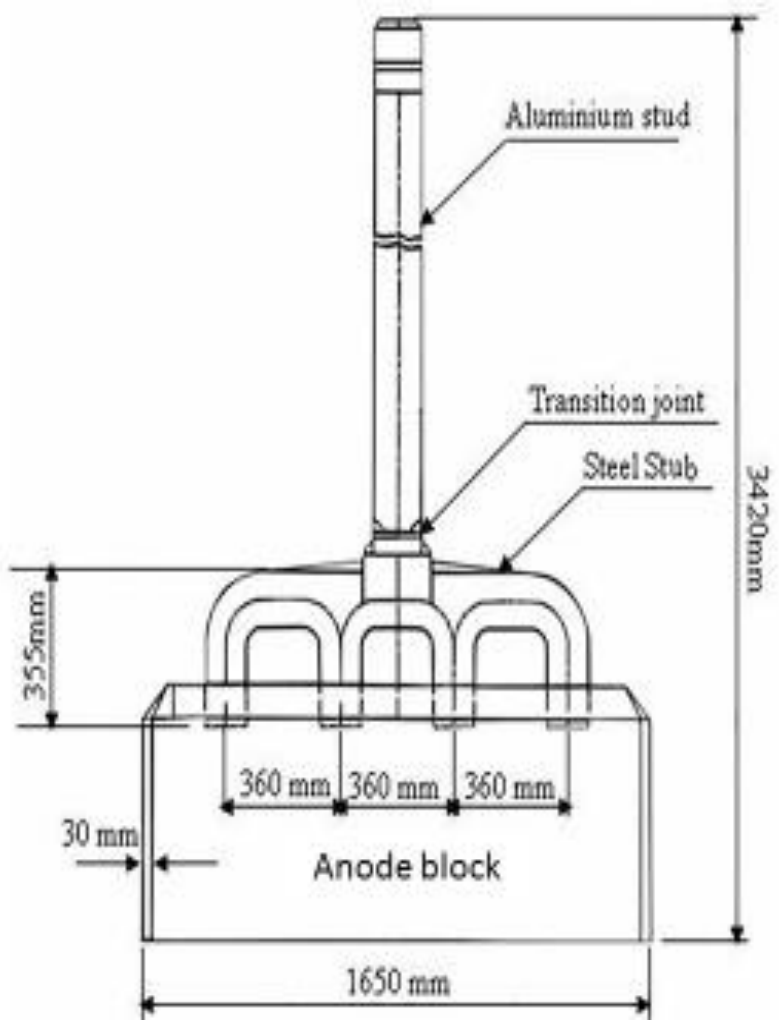

(a)

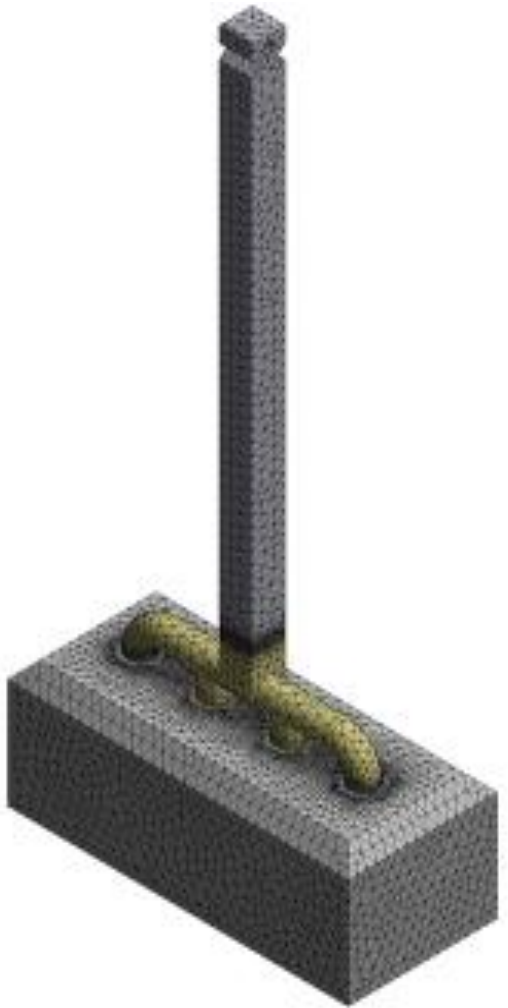

(b)

Figure 1 (a) Anode assembly dimensions[22], and (b) meshed model.

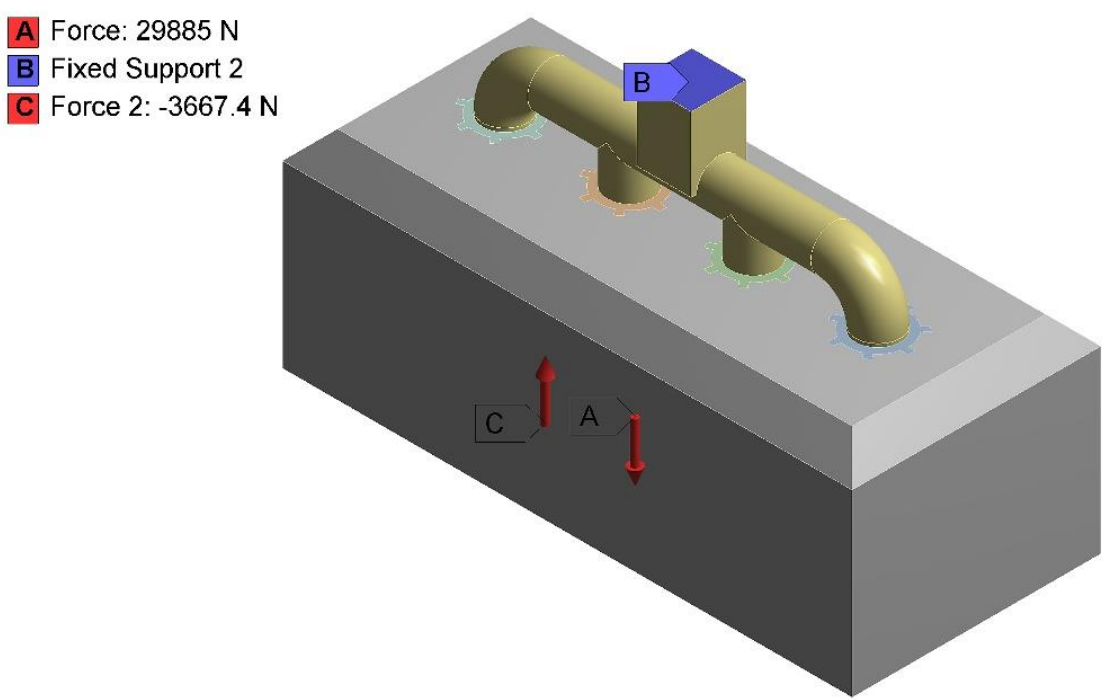

Figure $\mathbf{2}$ Mechanical boundary conditions of the finite element model.

\section{Thermo-electro-mechanical equations}

The details of thermo-electro-mechanical equations are found elsewhere [21, 34].

\section{Experimental work}

Ten prebaked cells working at $214 \mathrm{kA}$ with twenty four anodes per cell were selected at Egyptalum smelter (End to End arrangement) to measure the temperature and voltage of various positions on the anode assembly as illustrated in Figure 3. An infrared thermometer (Fluke 568 instrument device) was used to measure the temperatures. Emissivity compensation is only effective in temperature measurements, so the emissivity value varies with change the used material [30]. The emissivity of aluminium stud, steel stubs, cast iron and carbon block used in anode modeling were taken as 0.4, 0.88, 0.81, and 0.9 , respectively. The $A_{v D}$ was measured using Fluke $87 \mathrm{~V}$ millimeter [31]. 


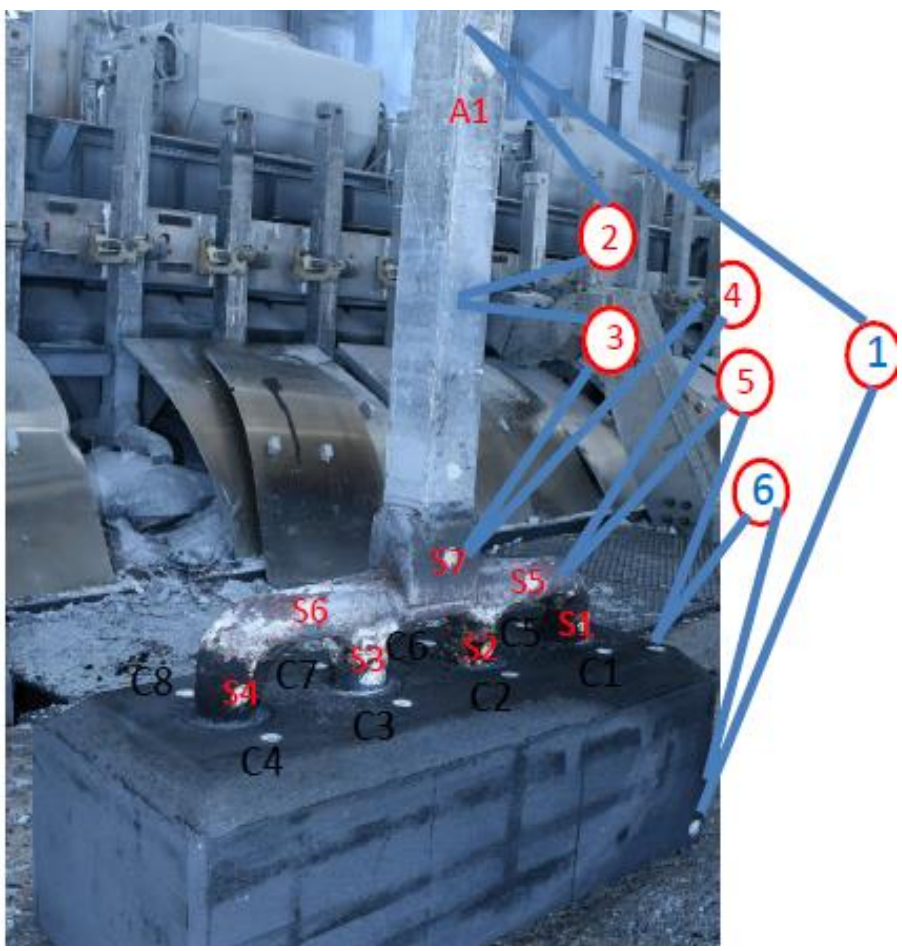

Figure 3 Locations of temperatures measurement (C1 to C8- denote to carbon-, S1 to S5 denote to steel-, and A1- denotes to aluminium) and voltage measurement (numbers 1 to 6 ) on the anode assembly.

\section{Results and Discussion}

\section{A. Measurements results}

The measured temperatures at the selected positions on the anode for ten cells and its comparison with modelled results are shown in Table 1. The temperature increases with moving down towards the bottom of the anode. The average temperatures of aluminium stud, yoke, stubs and carbon block are 166, 366, 404 and $503^{\circ} \mathrm{C}$, respectively. The measured $A_{V D}$ is $342.7 \mathrm{mV}$ (see Table. 2). Maximum voltage drop was observed between steel stub and carbon block.

Table 1 Measured temperatures on the anode assembly for ten cells and its comparison with the modelled results.

\begin{tabular}{|c|c|c|c|c|c|c|c|c|c|c|c|c|c|c|}
\hline $\mathrm{Ce}$ & No. & 616 & 618 & 620 & 621 & 623 & 626 & 627 & 628 & 632 & 633 & \multirow{3}{*}{$\begin{array}{c}\text { Average } \\
\text { measured } \\
\text { temp. }\end{array}$} & \multirow{3}{*}{$\begin{array}{l}\text { Modelled } \\
\text { temp. }\end{array}$} & \multirow{3}{*}{$\begin{array}{l}\text { P.D } \\
, \%\end{array}$} \\
\hline \multicolumn{2}{|c|}{ Anode block No. } & 5 & 15 & 3 & 17 & 17 & 8 & 8 & 8 & 2 & 8 & & & \\
\hline Title & Location & \multicolumn{10}{|c|}{ Measurement temperatures, ${ }^{\circ} \mathrm{C}$} & & & \\
\hline 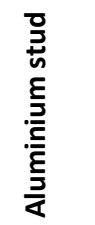 & A1 & 154 & 166 & 165 & 170 & 172 & 158 & 151 & 167 & 180 & 179 & 166 & 169 & 2 \\
\hline \multirow{3}{*}{ 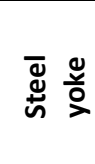 } & S5 & 357 & 360 & 387 & 355 & 376 & 367 & 355 & 352 & 378 & 380 & \multirow{2}{*}{366} & \multirow{2}{*}{340} & \multirow{2}{*}{8} \\
\hline & S6 & 360 & 358 & 360 & 357 & 374 & 356 & 362 & 355 & 378 & 385 & & & \\
\hline & S7 & 300 & 320 & 318 & 323 & 332 & 327 & 299 & 310 & 305 & 330 & 313 & - & - \\
\hline \multirow{4}{*}{ 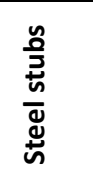 } & S1 & 365 & 369 & 382 & 375 & 354 & 380 & 380 & 370 & 384 & 440 & 389 & 425 & 8 \\
\hline & S2 & 395 & 402 & 410 & 399 & 402 & 418 & 389 & 385 & 398 & 420 & 403 & 411 & 2 \\
\hline & S3 & 394 & 399 & 415 & 402 & 410 & 425 & 406 & 411 & 397 & 425 & 409 & 413 & 1 \\
\hline & S4 & 420 & 395 & 412 & 403 & 408 & 416 & 412 & 396 & 405 & 433 & 414 & 428 & 3 \\
\hline \multirow{8}{*}{ 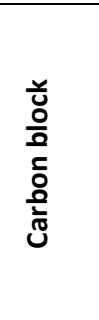 } & C1 & 500 & 525 & 544 & 506 & 535 & 558 & 540 & 537 & 532 & 489 & \multirow{8}{*}{503} & \multirow{8}{*}{490} & \multirow{8}{*}{3} \\
\hline & C2 & 510 & 518 & 542 & 495 & 527 & 546 & 510 & 522 & 519 & 544 & & & \\
\hline & C3 & 500 & 517 & 523 & 512 & 544 & 532 & 498 & 498 & 507 & 571 & & & \\
\hline & C4 & 508 & 514 & 520 & 505 & 533 & 541 & 501 & 497 & 496 & 552 & & & \\
\hline & C5 & 498 & 505 & 515 & 502 & 520 & 533 & 495 & 491 & 503 & 470 & & & \\
\hline & C6 & 502 & 510 & 532 & 511 & 523 & 544 & 497 & 512 & 501 & 540 & & & \\
\hline & C7 & 505 & 530 & 542 & 511 & 521 & 545 & 533 & 522 & 512 & 545 & & & \\
\hline & C8 & 455 & 462 & 433 & 452 & 450 & 441 & 429 & 435 & 425 & 465 & & & \\
\hline
\end{tabular}


Table 2. Measured voltage drop on the anode assembly for ten cells and its comparison with the modelled results.

\begin{tabular}{|c|c|c|c|c|c|c|c|c|c|}
\hline \multirow[b]{2}{*}{$\frac{\dot{0}}{\overline{\underline{d}}}$} & \multirow[b]{2}{*}{ 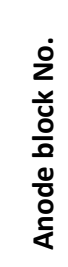 } & \multicolumn{6}{|c|}{ Voltage drop, $\mathrm{mV}$, measured between } & \multirow[b]{2}{*}{$\begin{array}{c}\text { Modelled } \\
\text { voltage drop } \\
\text { between Alum- } \\
\text { Carbon, mV }\end{array}$} & \multirow[b]{2}{*}{$\begin{array}{r}\text { P.D. } \\
\text {, }\end{array}$} \\
\hline & & 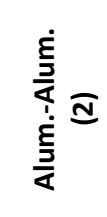 & 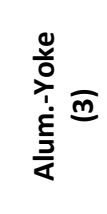 & 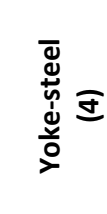 & 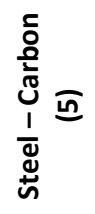 & 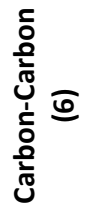 & $\begin{array}{l}\frac{5}{0} \\
\frac{0}{2} \\
\frac{1}{d} \\
\frac{1}{3} \\
\frac{5}{\alpha}\end{array}$ & & \\
\hline 616 & 5 & 20 & 20 & 133 & 139 & 32 & 342 & & \\
\hline 618 & 15 & 22 & 22 & 129 & 140 & 34 & 344 & & \\
\hline 620 & 3 & 24 & 21 & 126 & 137 & 33 & 345 & & \\
\hline 621 & 17 & 21 & 24 & 134 & 132 & 35 & 348 & & \\
\hline 623 & 17 & 19 & 24 & 125 & 140 & 36 & 341 & & \\
\hline 626 & 8 & 21 & 22 & 125 & 141 & 35 & 342 & & \\
\hline 627 & 8 & 30 & 19 & 130 & 135 & 32 & 340 & & \\
\hline 628 & 8 & 20 & 19 & 124 & 164 & 30 & 340 & & \\
\hline 632 & 2 & 21 & 20 & 134 & 138 & 31 & 341 & & \\
\hline 633 & 8 & 19 & 21 & 125 & 145 & 30 & 344 & & \\
\hline \multicolumn{2}{|c|}{ Average } & 21.7 & 21.2 & 128.5 & 141.1 & 32.8 & 342.7 & 355 & 3 \\
\hline
\end{tabular}

\section{B. Validation of the base model}

Model validation was considered an important step when creating a mathematical model [32]. The base model was validated in the following items:

- In the thermal model, the percentage difference (P.D) of temperature between the measured and modelled results don't exceed $10 \%$ as shown in Table 1 . This percentage is acceptable to validate the thermal model. Small differences (1- $3 \%$ ) in temperature are observed between modelled and measured values at locations $\mathrm{A} 1, \mathrm{~S} 2, \mathrm{~S} 3$ and $\mathrm{S} 4$ and $\mathrm{C} 5$. Maximum temperature difference (8\%) is observed in steel yoke (S5) and at steel stub location (S1). The low in the P.D is agreed with the data published elsewhere [7], where the P.D between the predicted and measured values varied from 2 to $13 \%$.

- In the electrical model, the Avd is $355 \mathrm{mV}$. While the P.D between the modelled and the measured $(342.7 \mathrm{mV}$ as shown in Table 2 ) result is about $3 \%$. Also, this percentage is adequate to validate the electrical model as discussed elsewhere [5, 7].

- In the mechanical model, the validity of this model can be confirmed by making the free-body diagram of pressures operating on the steel stubs as shown in Figure $4(a, b)$. Two types of forces (force due to the weight of carbon block on the bath and the applied force at the bottom of the anode block taking into account the buoyancy force exerted by the bath) were applied to the steel stubs as illustrated in Figure 2. These forces led to the appearance of maximum pressure in the middle of the steel stubs as illustrated in Figure 4 (a), and this corresponds to the result of the free body diagram Figure 4 (b).

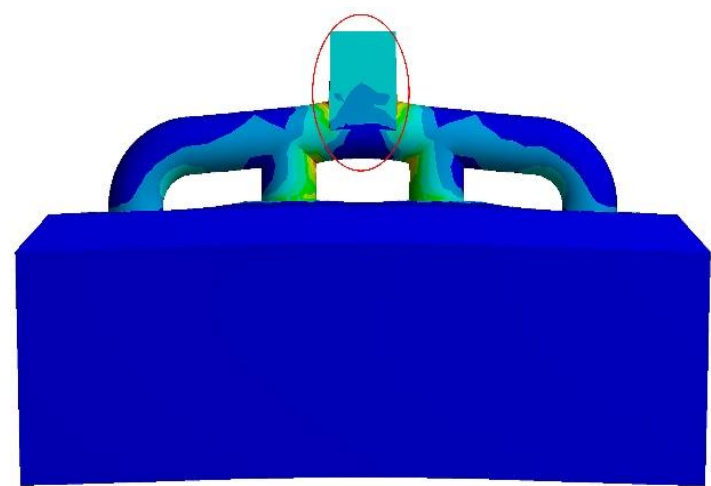

(a)

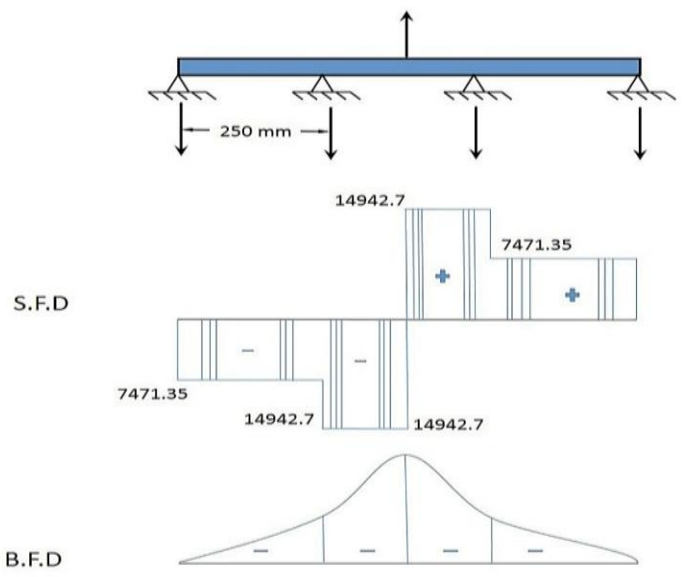

(b)

Figure 4 (a) Distribution of applied forces in steel stubs and (b) free body diagram for steel stubs. 


\section{Results and Discussion of the Cases Studies}

Three cases were investigated in this study. Temperature, voltage, and pressure distribution of these cases were studied and compared to the base case. The boundary conditions were standardized for all cases, as in the base case.

Case 1: Effect of deterioration and enlargement of stub diameter on the voltage drop and principal stress

The designed stub diameter $(130 \mathrm{~mm})$ was changed to various diameters $(110,120,140,150,160$ and $170 \mathrm{~mm})$, which represent the different stages of deterioration or size enlargement of the stub diameter. In each case studied, the hole diameter in the anode block doesn't change (195 mm), while the stub diameter changed. This means that cast iron thimble has changed and hence the mass of cast iron has changed. The results showed a decrease in the AvD with increasing stub diameter (Figure 5). Increasing the voltage drop is caused by decreasing the contact resistance, and this is based on the air gap between steel stub and carbon block. If the cast iron thimble size is reduced, this position may cause the anode mass to fall into the electrolytic bath. So, choosing the optimum stub diameter depends directly on the mechanical aspects. The relationship between stub diameter and maximum principal stress (MPS) on the steel stubs also shown in Figure 5. MPS decreases from 2.93 MPa at the stub diameter of $110 \mathrm{~mm}$ to $1.85 \mathrm{MPa}$ at the stub diameter of $110 \mathrm{~mm}$ and then increases for the stub diameter more than $140 \mathrm{~mm}$. The increase in MPS after stub diameter $140 \mathrm{~mm}$ may be due to the decrease in cast iron thickness. The calculated data were significantly lower than the maximum experimental value of tension stress, estimated at $8 \mathrm{MPa}$ [29]. This result indicates the stub diameter of $140 \mathrm{~mm}$ with hole diameter $195 \mathrm{~mm}$ and $22.5 \mathrm{~mm}$ gap filled with cast iron is safe from all side of thermal and mechanical aspects.

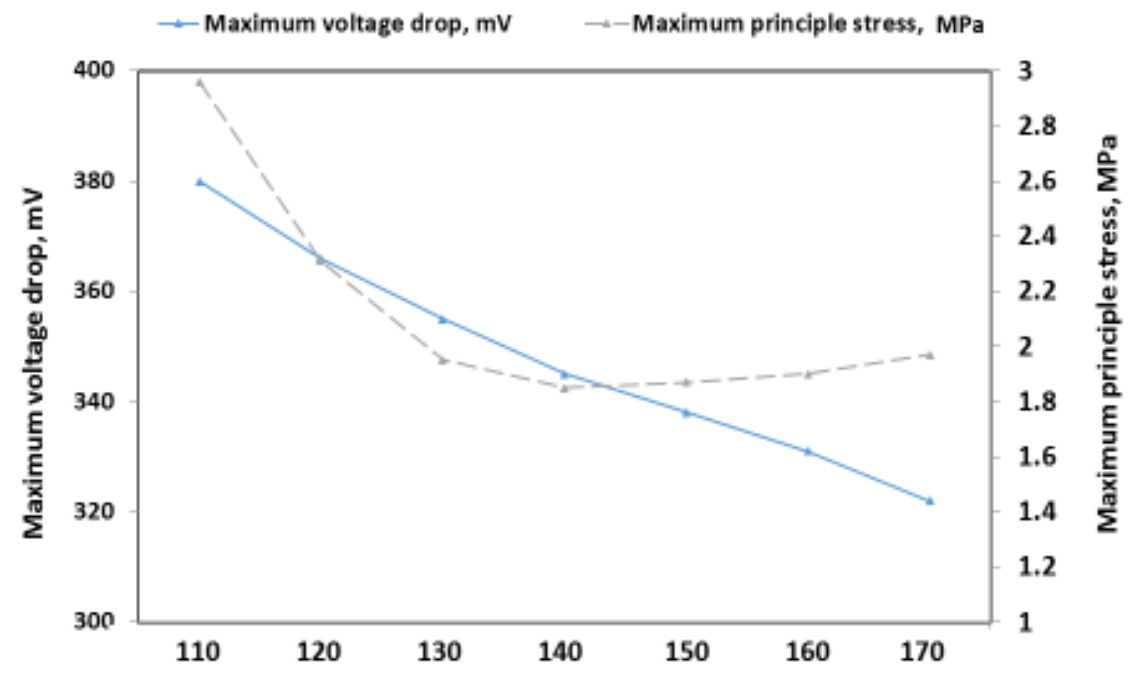

Stub diameter, $\mathrm{mm}$

Figure 5 Relation between stub diameter with maximum voltage drop and maximum principle stress.

\section{Case 2: Effect of cast iron thimble flutes number on the anodic voltage drop}

The various number of cast iron thimble flutes $(4,5$, and 7$)$ were simulated with the optimum design of stub diameter from case 1 (140 $\mathrm{mm}$ ) and compared with the base flutes design (6). Table 3 summarized the comparison between the different numbers of flutes with the $A_{V D}$. It can be seen that the maximum $A_{V D}$ decreases from 349 to $344 \mathrm{mV}$ when the flutes number increase from the 6 to 7 .

This result means that $1 \mathrm{mV}$ can be saved by increasing the number of flutes from 6 to 7 . However, it is important to note that 7 flutes require approximately $4.13 \%$ more in cast iron compared with the base case. So, the thimble flutes number might have a little effect on the design of anode stub hole.

Table 3 Relationship between numbers of flutes with anodic voltage drop.

\begin{tabular}{|c|c|c|c|c|}
\hline Number of flutes & Contact area, $\mathbf{m}^{\mathbf{2}}$ & Cast iron volume, $\mathbf{m}^{\mathbf{3}}$ & Cast iron mass, $\mathrm{kg}$ & Voltage drop, $\mathbf{m V}$ \\
\hline 4 & 0.140 & 0.00106 & 7.753 & 349 \\
\hline 5 & 0.146 & 0.00110 & 8.102 & 346 \\
\hline 6 & 0.152 & $1.15 \mathrm{E}-03$ & 8.451 & 345 \\
\hline 7 & 0.158 & $1.20 \mathrm{E}-03$ & 8.800 & 344 \\
\hline
\end{tabular}


Case 3: Effect of steel stubs number on the temperature, voltage drop, and principal stress of the anode assembly

Effect of changing the number of steel stubs from the designed value (4) to 3 and 5 was investigated on the anode temperature, $A_{V D}$ and MPS. The optimized results from the previous cases were taken into account (stub diameter of $140 \mathrm{~mm}$, yoke height of $80 \mathrm{~mm}$ and cast iron thimble flutes number of seven) during this case. Electric potential in the anode block more distributed in 5 steel stubs as compared with 4 or 3 steel stubs. The AvD decreases from 370 to 344 , and $333 \mathrm{mV}$ with increasing the steel stubs number from 3, 4, and 5 , respectively. This result means that $11 \mathrm{mV}$ can be saved by increasing the number of stubs from 4 to 5 . W. Li, et.al [6] has reported that the same numbers of steel stubs $(3,4$ and 5$)$ were used in other design. Their results showed a decrease in the $A_{V D}$ from 397 to $310 \mathrm{mV}$ at

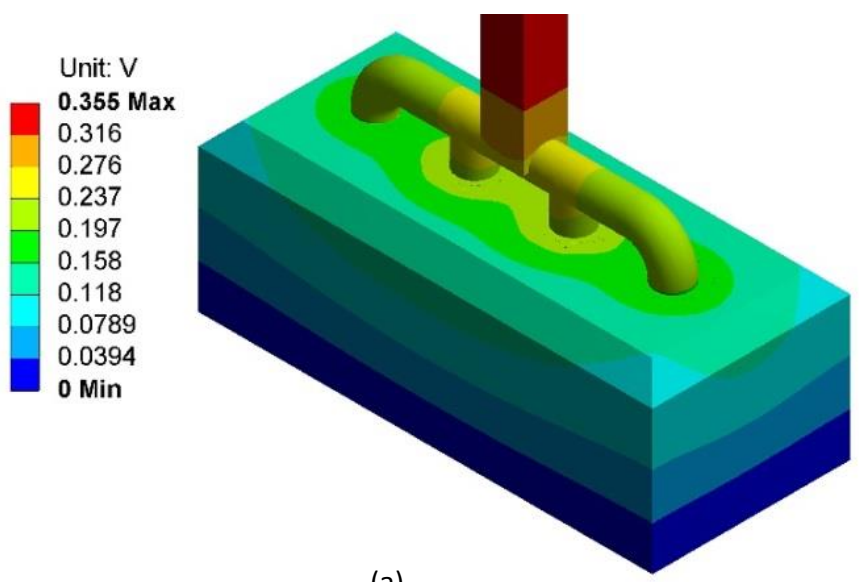

(a)

Figure 6 Anodic voltage drop distribution for (a) 4 and (b) 5 steel stubs different operation conditions. Figure $6(\mathrm{a}, \mathrm{b})$ represents a voltage drop at various stub number ( 4 and 5 ). As assumed in the boundary conditions that the bottom of the anode block was set to zero voltage. Thus, it can be concluded that the electric potential at the top of the aluminium stud represents the maximum $A_{v D}$. The maximum $A_{v D}$ decreases with increasing the number of steel stub from 4 to 5 . The central stubs appear to have the highest voltage-drop, and this result can be explained by the electric current moves throughout the shortest possible path to the bottom of the carbon block. On the other hand, the MPS decreases with increasing the steel stub from $2.16 \times 105$ to $2.07 \times 105 \mathrm{~Pa}$. Moreover, increase the stress in the center of the anode block agree with the assumption that the compressive stress in the anode block increases due to radial pressure caused by yoke bending [7].

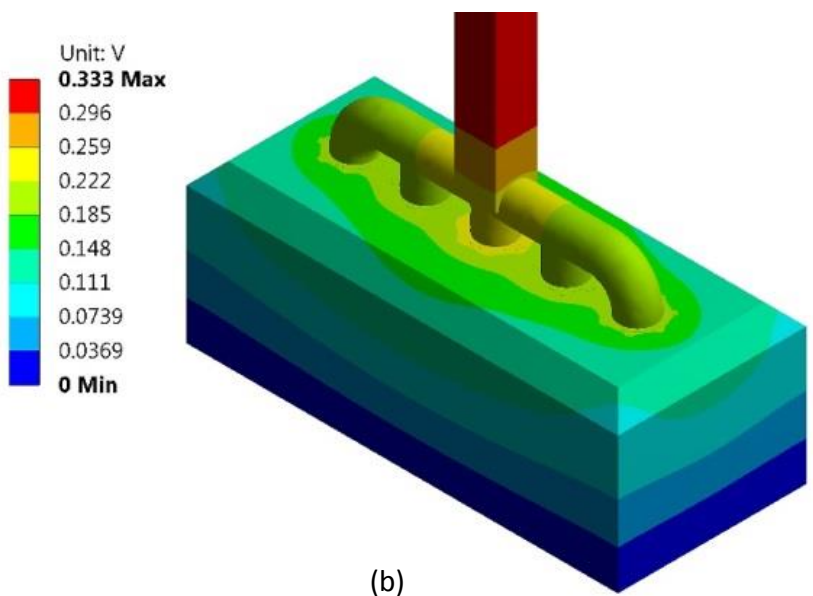

The mechanical stress distribution over steel stub is shown in Figure $7(a, b)$. The MPS decreases from 1.7E6 to 1.32E6 Pa with increasing the steel stub number. This result agreed with the calculations in Figure 4 that the MPS appears in the middle point of steel stub, and decreases with increasing the stub number [33]. The negative stress values in these figures are compressive stress and maybe cause fatigue or breakdown.

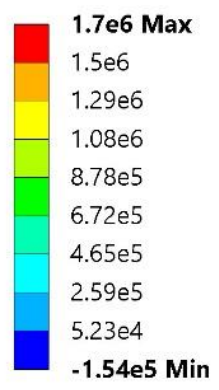

1.54e5 Min

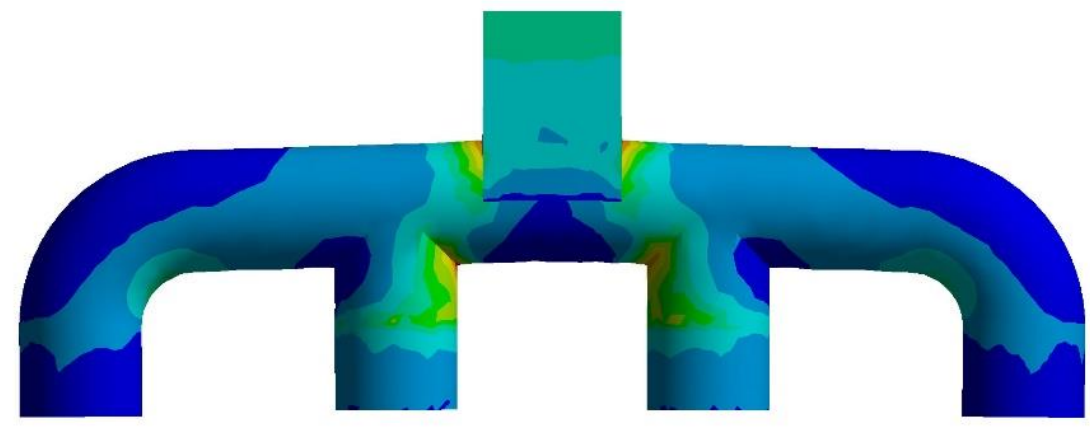

(a) 

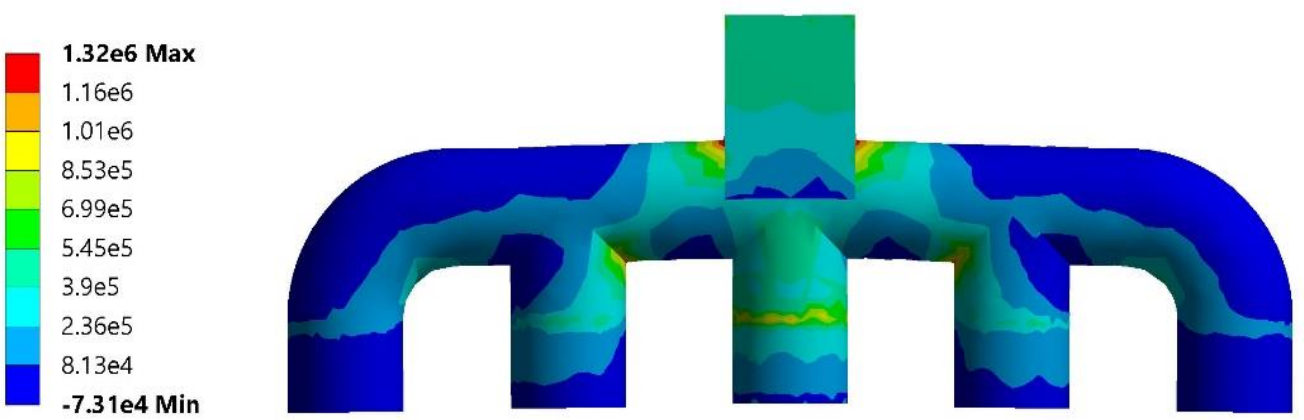

(b)

Figure 7 Stress distribution models of the steel stub numbers for (a) 4 and (b) 5 .

\section{Conclusions}

A numerical study of three-dimension thermal-electrical under mechanical loading of anode assembly was investigated using a FEM program (ANSYS). The base model was validated based on real measurements at Egyptalum smelter. The obtained result showed good agreement of temperature, voltage and stress distribution. The results showed that stub diameter of $140 \mathrm{~mm}$ is the optimum design of providing a minimum voltage-drop ( $344 \mathrm{mV}$ as compared with 355 $\mathrm{mV}$ for the base design) and minimum stress (1.85 MPa for $140 \mathrm{~mm}$ as compared with $1.93 \mathrm{MPa}$ for $130 \mathrm{~mm}$ ). The electric potential in carbon anode with 5 stubs was more evenly distributed and more saving in electrical energy. The anodic voltage drop decreases from 344 to $333 \mathrm{mV}$ with increasing the steel stubs number from 4 to 5 , respectively. Finally, this numerical study provides an optimum operating parameters that could improve the cells performance in general and the Egyptalum smelter in particular.

\section{Funding sources}

This research received no external funding.

\section{Conflicts of interest}

There are no conflicts to declare.

\section{Acknowledgements}

The authors would like to express his appreciation to the Chairman and Chief Executive Officer of Egyptalum for his support during this study, and also to all staffs of Egyptalum for their continuous encouragement and supply of valuable data. The authors would like to express his appreciation to Prof. Ahmed A. Atlam for his cooperation during this work, Associate Prof. Abdalla Abdal-hay for his supporting during this study and Prof. Abdel Salam Hamdy Central Metallurgical R\&D Institute, CMRDI, Cairo, Egypt for revision this paper.

\section{References}

[1] H. Kvande and P. A. Drabløs, The Aluminum smelting process and innovative alternative technologies, Journal of Occupational and Environmental Medicine, Vol. 56, (2014), pp. S23-S32.

[2] M. Dupuis, How to limit the heat loss of anode stubs and cathode collector bars in order to reduce cell energy consumption, TMS light Metals, (2019), pp. 521-531.

[3] K. Grjotheim and H. Kvande, Introduction to aluminum electrolysis: Understanding the Hall-Hérloult process, Düsseldorf: Aluminium-Verlag, 1993.

[4] D. R. Gunasegaram and D. Molenaar, Towards improved energy efficiency in the electrical connections of Hall-Héroult cells through finite element analysis (FEA) modeling", Journal of cleaner production, Volume 93, (2015), pp. 174-192.

[5] M. Fortin, N. Fafard, and P. Goulet, FEM analysis of voltage drop in the anode connector assembly, TMS Light Metals, Vol. 1, (2009), pp. 1055-1060.

[6] Li, J. Zhou, and Y.-w. Zhou, Numerical analysis of the anode voltage drop of a reduction cell, TMS Light Metals, (2009), pp. 1169-1171.

[7] S. Beier, "A study of an anode assembly with focus on the anode connection used in aluminium reduction cells", M.Sc., Auckland university, 2010.

[8] E. Jeddi, Numerical study of anodic voltage drop in the HallHéroult cells by finite element method, M.Sc., Qubec University, 2013.

[9] C. Schmitz, J. Domagala, and P. Haag, Handbook of aluminium recycling, Essen: Vulkan, 2007

[10] H. Fortin, N. Kandev, and M. Fafard, FEM analysis of voltage drop in the anode connector induced by steel stub diameter reduction, Finite Elem. Anal. Des., Vol. 52, (2012), pp. 71-82.

[11] A. Lagerstedt, J. Kron, F. Yosef, and H. Fredriksson, Measurements and modeling of air gap formation in iron-base alloys, MSA Materials Science \& Engineering A, Vol. 413, (2005), pp. 44-51. 
[12] D. Richard, M. Fafard, R. Lacroix, P. Cléry, and Y. Maltais, Carbon to cast iron electrical contact resistance constitutive model for finite element analysis, Journal of Materials Processing Technology Vol. 132, no. 1-3, (2003), pp. 119-131.

[13] G. E. Totten and D. S. MacKenzie, Handbook of Aluminum : physical metallurgy and processes, CRC Press, 2003.

[14] N. Kandev and H. Fortin, Electrical losses in the stub-anode connection: computer modeling and laboratory characterization, TMS Light Metals, (2009), pp. 1061-1066.

[15] M. M. Ali, A. Nofal, A. Kandil and M. Agour, Characterization of new cast iron alloys for the stub-anode connection in the aluminium reduction cells, Int. Journal of engineering research and application, Vol. 3, no. 5, (2013),pp. 414-419.

[16] D. Molenaar, B. Pillay, Y. Tsuji, and Y. Zhu, Challenges and successes of conducting trials for anode design modification", TMS Light Metals, (2018), pp. 1267-1274.

[17] Jing Liu, Hui Dong, Yu Mao, Jihong Mao, and Yungang Ban, Study on optimization of anode structure for aluminum reduction cell , TMS Light Metals, (2018), pp. 1275-1284.

[18] M. M. Ayoola Brimmo, Khalil Khaji, Mohamed I Hassan, Anode design modeling for improved energy efficiency, in ICSOBA 2015, Dubai, United Arab Emirates, pp. 1-10.

[19] R. W. Lewis, P. Nithiarasu, and K. N. Seetharamu. Fundamentals of the finite element method for heat and fluid flow, Chichester: Wiley, 2004.

[20] D. V. Hutton, Fundamentals of finite element analysis, Boston: McGraw-Hill Higher Education, 2004.

[21] ANSYS, Software program for finite element analysis system, vol. 16.1 workbench, 2015.

[22] M. Agour, Cast iron for anode fixation collars, M. Sc., Mining \&Petroluem Engineering, Al-Azhar University, Cairo, 2011.

[23] H. Abbas, Mechanism of top heat loss from aluminium smelting cells, ResearchSpace@ Auckland, 2010.
[24] B. Baharvand, M. Ameri Siahooei, and S. Khanbabapoor, Thermo-electrical modeling of an aluminum reduction cell, TMS Light Metals,(2018), pp. 761-768.

[25] J. Liu, H. Dong, Y. Mao, J. Mao, and Y. Ban, Study on optimization of anode structure for aluminum reduction cell, TMS Light Metals, (2018), pp. 1275-1284.

[26] D. Munger and A. Vincent, Electric boundary conditions at the anodes in aluminum reduction cells, Metallurgical and Materials Transactions B, Vol. 37 (6), (2006), pp. 1025-1035.

[27] S. Wilkening and J. Côté, Problems of the stub-anode connection", TMS Light Metals, (2007), pp. 534-542.

[28] S. Beier, J. J. Chen, H. Fortin, and M. Fafard, FEM analysis of the anode connection in aluminium reduction cells, TMS Light Metals, (2011), pp. 979-984.

[29] D. Richard, P. Goulet, O. Trempe, M. Dupuis, and M. Fafard, Challenges in stub hole optimisation of cast iron rodded anodes, TMS Light Metals, (2009), pp. 1067-1072.

[30] Fluke 568 infrared and contact thermometer. Available: http://en-us.fluke.com /products/thermometers/fluke-568thermometer.html, 2010, (acessed in 2016).

[31] F. Fluke $87 \mathrm{~V}$ industrial multimeter. Available: http://enus.fluke.com/products/digital-multimeters/fluke-87v-digitalmultimeter.htm|\#resources, 2010 (aceessed in 2016).

[32] M. Dupuis, "Process simulation," TMS Course on Industrial Aluminum Electrolysis, 1997.

[33] M. Ghoniem and M. El-Mihilmy, Design of reinforced concrete structures, Dar Elmaaref, Egypt, 2008.

[34] M. A.Aly, M. M. Ali, A. A. Atlem, A study of anodic voltage drop in aluminum reduction cell by finite element analysis, International Journal of Engineering Research and Applications,Vol. 6, no. 1, (2016), pp. 01-11. 